\title{
EFFECTS OF EXAMS ANXIETY AS PER GENDER VARIANCE AT SECONDARY SCHOOL LEVEL IN DISTRICT QUETTA
}

\author{
Nazia Anwar \\ Research Scholar, Institute of Educational Research, \\ University of Balochistan, Quetta, \\ Pakistan \\ Email: nazia.anwar77@gmail.com

\section{Bushra Batool} \\ Lecturer, Institute of Educational Research, \\ University of Balochistan, Quetta, \\ Pakistan
}

\begin{abstract}
Test anxiety has got universal attention of several researchers working in the field of education during recent years due to its positive or negative impact on students' academic achievements. The current study intended to evaluate the gender variation in test anxiety level at secondary school level in Public Schools in District Quetta. The descriptive research design with quantitative research technique is utilized for data collection. The participants of the research study were 172 (102 boys, 70 girls) Students. "Westside Test Anxiety Scale, was used for measuring test anxiety scores. For evaluating the variance among gender in Test anxiety Average scores, an Independent sample $t$ - test was performed with SPSS. The result indicated the prevalence of anxiety in boys and girls, but no statistically significant variation was detected in genders. The finding of the study has educational implication for educational institutes and professional assistance for recommendations educationalists, counsellors and other concern bodies, further the study has fundamental help for students in coping anxiety in evaluative circumstances.
\end{abstract}

\section{KEYWORDS}

Exam anxiety, Academic achievements, Gender 


\section{INTRODUCTION}

Competition among the human race is increasing day by day. The world is turning over new challenges in everyday life for humanity. These challenges may be related to achievements in the personal or professional or educational life of a person, such challenges generated stress and depression, Human progress is not related to its personal desires only, but it is a combination of others, desires and expectations from him/her. In our education system high expectations of parents, teachers, and society force the students in a continuous state of depression and stress. These stressors effectively participating in creating an emotional condition in human mind widely known as anxiety.

\section{Anxiety}

As a philosophical and theoretical speculation about anxiety, the credit goes to (1949) Sigmund Freud, the first psychologist who had recognized the phenomena of anxiety. According to Sigmund Freud anxiety was defined as an "emotional state" that would be "felt something", it is physiological arousal with feelings of worry, tension, nervousness and apprehension. In psychoanalytical research, fear was assumed as a logical reaction in treacherous circumstances. Whereas, anxiety was assumed as a devastating response sometimes, ill logical and destructive for the human in a threatening situation. (Harris et.al, 2013).

Anxiety is considered as a hidden culprit which triggers inappropriate behaviours in human. Anxiety can be identified as a hidden disability, apparently students look fine but then mysteriously burst out due to hidden stress. (Minahan. J et al ,2012; Harris et.al, 2013). The issue of anxiety got psychological researchers' attention in 1936 and documented as a serious problem for mental health. In 1950s western researcher incited their focus towards the effects of anxiety in the test, public presentations, and social gatherings. Earnest work began in 1952 at "Yale University" on anxiety. Sigmund Freud provides three perception of anxiety (1) "reality anxiety" when the source of threat is environmental (2) "neurotic anxiety" when the source of threat is forbidden, unconscious desires (3) "moral anxiety" when the conflict between id and superego, a moral guilt become a cause of threat. A perceived threat will convert into a strong conviction, which forced a person to shatter its self-confidence, self-worth and develop believes on negative ideas about selfconcept. by overreacting in fearful competitive situations. (Kleinknecht \& Ronald, 1990). 
As Breuer (1999) revealed that all types of anxiety disorders are the result of two-fold characteristics of physiologic hyper arousals and extreme emotional fear. According to APA (American Psychological Association) "Anxiety is characterized by feelings of tension, worried thoughts and physical changes. Anxiety disorders such as panic disorder and obsessive-compulsive disorder (OCD) cause recurring intrusive thoughts or concerns and physical symptoms such as sweating, trembling, dizziness or a rapid heartbeat" (Encyclopedia of Psychology,2000).

\section{Test anxiety}

In 1952, the concept of anxiety was instigated to be investigated, when (Sarason \& Mandler, 1952) developed an instrument which was used to assess personal differences in anxiety scales "Test Anxiety Questionnaire" for adults .Later in 1960 (Sarason, Davidson, Lighthall) followed to introduced an instrument " Test Anxiety Scale for Children" for calculating test anxiety in children and issued many research studies on the effects of test anxiety on performance. (Liebert \&Morris ,1967) anticipated test anxiety "TA" is a amalgamation of two containing of the components known as emotion and worry. Emotionality is an automatic response to a situation, for instance, high blood pressure, sweetening, or fast heartbeat. Worry related to cognitive response in a situation like over thinking about result or recalling memory again and again. Both components were experimented by the researcher and the results reported that emotional aspect only affected if the cognitive aspect had a low effect otherwise cognitive factor had directly influenced the performance during testing or evaluative conditions. (Morris \& Liebert, 1969).

Extreme level anxiety hindered the student's performance capabilities even if they have cognitive potential to accomplish the desire scores, but societal pressures of scoring high in test potentially impair the vocational and academic opportunities. Test anxiety describes as "behavioural constellation that has devastating influences on educational performance". (Zeidner, 1990; Kirkland \& Hollands worth ,1980) Test anxiety can be defined as "The anxiety is a combination of different responses behavioural, physical and phenomenological". Patrick (1934) determines anxiety as human behaviour under extreme stress. Human problem-solving skill dramatically changed in stressful surroundings. The literature (Zeidner, 1998) provided ample evidence, that the test anxiety has related to student's study habits. 


\section{Examination}

The questioning was one of the traditional methods introduced by Socrates for Assessing scholars' knowledge, learning and critical thinking abilities. Latterly, written examination / testing system was introduced in 1792 at England University of Cambridge (Trifoni. A at el 2011). Examination and tests are considered a powerful source of evaluation of performance \& skills, but the current set structure of examination become a stressful burden for the learners (Tobias. S, 1979).

According to Mathew's (1985) "Examination process testify the efficiency of the education. We need to test what a student can do, rather what he knows". Although the examination system is the most beneficial system of measuring the performance during the educational era, but the current examination system is just increasing a load of contents on learners' shoulder. Consequently, anxiety affecting the emotional, physical, intellectual development of the learner. (Tobias.S,1979). The foremost aim of the examination is to scrutinize the learner's capabilities of learning, scrutinize problem-solving skills by taking answers of different question on the question paper or finding a solution of the given problem under certain circumstances executed by the examiner. The conservative system of education we are following in Pakistan becoming the cause of many mental health problems like insomnia, anxiety, stress, maladjustment etc, due to all these mental health issues performance and achievement rate of students is also affecting in the examination. (Rasul.S et al 2011).

\section{Gender variation}

Several studies were conducted on analysing variation in the anxiety level among male and female students (Zahrakar,2008; Rezazadeh \& Tavakoli, 2009; (Ergene.T et al,2011; Farooqi.Y.N at el,2012 ).Many researches proclaimed similar level of test stress and worry among male and female students. Both genders are facing almost same type of circumstances in evaluative situation due to that presences of anxiety was indicated in most of the studies, the variation was due to their perception of threat, scholastic abilities of coping with anxiety, emotional reactions in evaluative conditions ,study habits, intelligence level (Zeidner's , 1990).

Amongst sufferer's female were reported with high anxiety compare to male students. The explanation for this difference was emotionality element and 
social discriminating rules for male and females. (Sharma.S,et al,1990) female learners were found to be more sensitive and anxious in threatening conditions. Fear of failing in exams, incarnated jealous among fellows raise the stress level in females. On the other hand's males were exhibited less anxious behaviour because the learned to cope with anxiety easily, they were found to be more defensive, denied threats of failures as considering the feeling of fear was against masculinity.(Hembree,1988; Zeidner, 1990; Rezazadeh \& Tavakoli, 2009; Farooqi.Y.N. at el, 2012; Numan \&Hasan, 2017)

\section{Anxiety Types}

\section{Generalized anxiety disorder}

This type of anxiety provoked by, it's chronical in nature. People experiencing GAD, exaggerated tensions and worries, always expect uncertainty and feel nervous about wealth, health, relationships and social activities in routine life, Symptomatology; insomnia, muscles pulling, tiredness, exhaustion.

\section{Obsessive compulsive disorder}

This nature of anxiety categorized through obsession undesirable judgements, compulsion repetitive actions, reoccurring behaviours and rituals, like checking house before leaving many times, repeatedly washing hands, excessive cleanliness obsession, taking too much medicines, taking bath etc. Performing such rituals offer impermanent relief.

\section{Panic disorder}

This type of anxiety has repeated panic attacks with physical symptoms. Irresistible feeling of reoccurring fear or feeling of predicating threat. Symptomatology; palpation, chest pain, dizziness, pounding heart, chill sensations, trembling, shortness of breath, nausea, derealization, hallucination, craziness and paranesthesia. Extreme panic attacks lead towards agoraphobia, such as fear suffocation in crowded markets, local trains and lifts, confine spaces, fear of height.

\section{Post-traumatic stress disorder}

This nature of anxiety can develop when an individual practice dreadful condition or terrifying event in his/her life, accompanied with physical harm. Later that person re-experiences that event repeatedly in nightmares /day dreams. The traumatic incident that generates PTSD are mostly military combat, natural disasters, childhood abuse, personal assaults, rape victim. 
Social Phobia. This type of anxiety disorder is categories by extreme levels of self-consciousness in social life. A person experiencing social phobia has fears like difficulty in speaking in front of large groups, eating in front of others, making friends. (Shiri, Akhavan, \& Geramian, 2012).

\section{Ground realities of causing test anxiety}

i. Anxiety recognized as learned behaviour, causes due to connection of personal worth and worry of scoring high.

ii. It causes when a person is unable to control its emotions and thoughts.

iii. Lower self-esteem and self-efficacy cause anxiety.

iv. Embarrassing treatment from the teacher to students' cause anxiety.

v. Tasks or courses higher than students' mental abilities cause anxiety.

vi. Certain fears like isolation, family and societal pressure for gaining high grades also cause anxiety. impracticable parents' expectations.

vii. Poor time management during exams, i.e. completing the task within the given time rises anxiety level

viii. Inadequate skills and improper study habits

ix. Perfectionism, procrastination, confidence, low motivation

x. Self-criticism, negative self-talk (Sarason 1990; Zeidner, 1998).

\section{LITERATURE REVIEW}

Sullivan. H.S, (1949) Elucidated the concept of anxiety is different from fear. Although anxiety is an emotional state, which an individual is experiencing in a threatening situation, its concept is distinct from fear. Cognitional, psychological distress reflected in the shape of anxiety, whereas fear is the reflection of defense mechanism against external or predicted danger. In psychoanalytical research, fear was assumed as a logical reaction in treacherous circumstances. Whereas, anxiety was assumed as a devastating response sometimes, ill logical and destructive for the human in a threatening situation. There is a slight distinction between anxiety and fear which is difficult to observe. Anxiety was threating to turn into a cliché and an overriding fact of the contemporary world. Origin of anxiety began in infancy of human being in the form of fear of unfamiliar things and situations and immaturity of life (Stöber \&Pekrun,2004). In uncertainty and fear situation like exam, anxiety is an emotional response that typically appears as natural human reaction. Usually when a person perceives any situation as a threat to its self -esteem or selfworth. Anxiety is very useful in avoiding the risky situation conversely anxiety has a gratuitous outcome at an extreme level (Sarason, 1988). According to 
Spielberg's (1995) the conception of anxiety explained that a person who had anxiety had been found ineffective in his performance and achievements.

In general conceptualist fear or doubt of not performing well in an evaluative circumstance give birth to "evaluative or test anxiety". Test anxiety is circumstantial exclusive trait that appear in threatening situation. where as in social dimension test anxiety is consider as a fear of being judge by others opinions and morals, in other words it is defamatory judgement by the society. In border definition test anxiety emphasized as a threat to self-esteem, as a fear of humiliation and failure in reaching the desire target (Spielbergs,1966). The literature provided ample evidence, that there is a close connection between pupil study behaviours and test anxiety. (Zeidner, 1998). Nervousness and fear an individual is experiencing in the evaluative atmosphere, this doubt of deterioration increase the risk of losing self-worth. (Putwain.D.,2007). Two basic components of concern and emotional responses produce Test anxiety. As physiological reactions have associated with emotionality and worry is linked with cognitive reactions in evaluative situations. (Liebert \& Morris, 1967; Zeidner, 1998).

The researcher highlighted the further significant causes which triggered test anxiety in different situation such as personal competencies, self-esteem, gender differences, school levels, racism and birth order. Highly anxious students had a strong fear of evaluation and facing failure. Usually such students had an external locus of control, always feel unprotective, conscious, less responsible, low tolerance and self-control, never accept failures and blame others for their failures in contrast to less anxious students. also declared as a cause of test anxiety. (Hembree. R, 1988). The research literature provided ample evidence that test anxious students showed lower performance in test situation (Sharma \& Sud,1990; McDonald, 2001; Eman \& Farooqi, 2005; Farooqi, Rafiq \& Ghazal, 2007). As situational anxiety stated as test anxiety which shattered the confidence, persuaded fear, tension, cognitive intrusion, mind hindering and all these conditions leads towards interference with working capacity of a person (Sarason \& Spielberger, 1989)

"Sarason" in 1950's, had defined anxiety as a powerful provocation, a stimulus and a learnt response in testing context, anxiety was a drive that functions automatically. Researcher wholeheartedly corroborates that performance insufficiencies of pupils in exams were consequences of cognitive factor and 
extreme test anxiety levels. Specifically, it appears that students may face mental intervention when preparing and taking exams. (Cassady \& Johnson, et al, 2001; Dusek ,1980).

Thus, results (Rana \& Masood 2010; Vitasar.P, et.al, 2010) strongly supported the statement that the cognitive interference, poor conceptualization of the content of exam preparation \&, problem in retrieving key information during the test was the result of cognitive anxiety which had greatly affected the academic performance. The results of the research were supporting the claim, that these reasons could be controlled by appropriate enthusiastic working in academic institutions for students. The literature further explored that anxiety not only cause impairment in educational activities but also interfered social activities of life, students with anxiety syndrome suffers from diversities of problems in studies, psychological and physical issues with health. Lack of concentration, difficulties in learning and memorization, panic attack during lesson, lack of confidence, sweating palm, high heartbeat problem in breathing, pain in stomach are indicator of high anxiety in any situation (Spielberger,1985; Ruffins, 2007).

Normally anxiety had considered as normal feeling of tension and stress all students are facing before or during all types of assessments, presentations or in competition. In the current era, advancement in information technology raised the standards of educational evaluation. The obligatory qualification for having admission in higher educational institutes and for getting higher jobs are top grades and high GPAs. These demands from system, increasing pressure on students to score high if they wanted to lead a successful future life according to designed culture. Exaggerated pressure increases depression, disappointment and negativity about personal perceptions which leads to anxiety which decremented academic achievement of students. (Rezazadeh \& Tavakoli, 2009; Rana \& Masood 2010; Vitasar.P, et.al, 2010).

Stober. J et al., (2004) study reported that the utter most requirement of new generation society is competitive and successful academic life with high grades The higher pressure of professionalism and needs of quantic knowledge emphasized on assessments of individuals for evaluating the performance standard, which resulted in anxiety and distress because the individual knows that judgment is used to assess his or her performance. the concluded results of the research proclaimed significant variation in anxiety level among male 
and female students. The study (Sharma.S,et al,1990) claimed that the role expectation conflict is the main factor of gender variation in anxiety level and lower educational performance. The investigation had disclosed performance and test anxiety had negative association. Amongst sufferer's female were reported with high anxiety compare to male students. The explanation for this difference was social discriminating rules for male and females. Females were in sever pressure throughout their educational era. Usually a female was found to be emotional, more sensitive and easily become anxious in threatening conditions, always fear of failing in exams, family pressure comparison with others, incarnated jealous among fellows all these facts became the cause and symptoms of higher anxiety rates in females. On the other hand's males were exhibited less anxious behaviour because the learned to cope with anxiety easily, they were found to be more defensive, denied threats of failures as considering the feeling of fear was against masculinity. (Rezazadeh \& Tavakoli, 2009; Farooqi.Y.N at el,2012 ). (Zahrakar,2008) research showed inconsistent verification that female and male reported different anxiety level. Research indicated female emotional nature, self-created worries were the causes of high anxiety (Hembree, 1988; Numan \&Hasan ,2017; Zeidner, 1990). The results stated no significant variation among female and male anxiety level in exams situation.

The (Zeidner, 1977) provided the best explanation for the findings that nowadays all the students are having similar attitude towards study habits, they spent most of their time on watching games on television like football, and on internet face book. The time they have before exams for preparing wasted in other activities. Pupils have only lasted few days or hours for studies before exam spontaneously unsatisfactory exams preparation results in high anxiety level. (Guress.A et al, 2010; Yousefi,. et.al, 2009; Ferdous.F, 2012). The findings of (Ergene.T et al,2011) persistent that study behaviour had negative conjecturer of test related anxiety. Effective study behaviour reflects in students' high rate performances and ineffective study behaviour expect low rate performance and high level of anxiety in test state. (Zeidner, 1998; Udeani, 2012; Numan \&Hasan ,2017).

It was concluded that enthusiasm to perform good and concentration in exam lessened distress during assessment environment in educational institution. Students' mental health may be use as a tonic to sustenance approaches like self-instructional training student counselling \& guidance, behavioural therapy, 
life development programs, study skills drill, optimistic thinking skills, relaxation exercise, mental simulation. (zameer. S et.al 2013; Rana, R \& Masood, N 2010). The research (Xiao. J et al., 2013) had highlighted the collective culture and examination-oriented system of education which results in stresses, academic anxieties in students. The practical allegations of this study were to analysis education policies and the system of entrance exam in colleges which fashioned academic stress in students at high level which alternatively effects their performance and results in entrance exams. Furthermore, the research proclaimed (Eysenck et al.,2009) that it would be difficult for highly anxious students to concentrate on the task and avoid distraction than less anxious students. Additionally, it had further affirmed that harmful effects of anxiety restricted the efficient functioning of brain and body, therefore proper strategies and techniques should be applied for enhancing student's compatibilities of handling anxiety and avoiding distraction. Students should thwart the transferring of concentration from task relevant things towards irrelevant things. The study supported the literature that cited cognitive worry factor and irrelevant negative thinking has negative association with achievement of learners. learners (Hembree's, 1988; Sarason,1984)

(Barrows, Dunn \& Lloyd, 2013) had asserted that anxiety and self -efficacy had an extreme influence on educational prosperity. When learner lose their selfconfidence and started underestimating their competencies, their overall concentration diverted towards worries of scoring high, which universally had effect on exam performance (Bandura, 1993). Their confidence in self-abilities enlightened the darkness of anxiety that had significant effect on marks and GPAs in single exams. Test anxiety would be easily controllable usually if its effect has a temporary impact, but become a serious issue and uncontrollable if anxiety had long lasting effects. (Barrows. J, et al, 2013; Cassady\& Johnson, 2002).

The work of. (Khan.M.S et al,2006) showed that stress has negative connection with cognitive functioning of students, therefore the researcher suggested rehabilitation and psychotherapy with the purpose to estimate the occurrence of anxiety and limit the effects of this illness. The study findings endorsed that this mental illness would not only have negative effects on students emotional, mental and physical development but have dangerous effect on society by increasing the rate of dropout form schools and colleges, suicide attempts, 
problems in marital life, weaken abilities to coping with difficulties in life (cited as Zoccolillo M.et al,1988; Khuwaja A.K,et.al, 2004).

The study further highlighted the remedial measures, which educational administrator and counsellor should follow and train students for facing critically anxious situations, managing themselves at all levels of learning. The term pronounces as score a person achieved in a test or assessment, are usually measured through standard set of scores. Attitude of students towards achieving the desire learning outcomes and scoring highly depend upon their own personal priorities. According to their personal concerns they adopted different techniques and strategies to achieve the desired target rate. (Eysenck et al 2009). Researcher asserted that teachers played vital role in anxiety releasing techniques for instance if they inform test anxious students about types of question asked in test, contents and aims of test, system use for evaluation and marking before organizing test. So, by this technique students become familiar to testing methods and their strange fear and detrimental influence of anxiety reduced to much extend sample exams questions and answers provides a clear frame work for attempting test questions. (Gürses.Aet,al ,2010; Ndirangu. G. Wet, al. 2009).

\section{OBJECTIVES}

1. To measure exam anxiety among students at Public Secondary schools, in District, Quetta.

2. To determine the anxiety score variation between boys and girls at Public Secondary schools, in District, Quetta.

3. To suggest the strategies of reducing anxiety during examination.

\section{RESEARCH HYPOTHESIS}

1. There is statistically insignificant gender variance in anxiety level at Public secondary schools, in District, Quetta.

2. There is statistically significant gender variance in anxiety level at Public secondary schools, in District, Quetta

\section{RESEARCH QUESTION}

1. To what degree anxiety levels varied among boys and girls at Public secondary schools, in District, Quetta? 


\section{RESEARCH METHODOLOGY}

\section{Research Design}

The research design has descriptive nature, survey design was carried out with quantitative research technique was followed in the current research for data collection

\section{Participants}

The constituted population in the present research were Students of the Public Secondary schools, in District Quetta.

\section{Sample and Sampling Technique}

The random sampling technique was used for the selection of examination centers from the district and convenient sampling technique was used for selecting students as a sample from the population. The sample consist of 172(102 male and 70 female) students of $10^{\text {th }}$ class of the Public Secondary schools, in District Quetta.

\section{Data collection Instrument}

For the purpose of data Adapted questionnaires "Westside Test Anxiety Scale" was used to measure test anxiety scores designed by "Richard Driscoll, (2004)". The scale had contained four items on measuring worry (cognitive) factor and anxiety and other six items are measuring impairment of anxiety on students but no item for over arousal physiological factors (Mary.R.A,et.al,2014) .5 Likert scale questionnaire had consist of statements "Not at all / Never True with scaled as (1)" , "Slightly / Seldom true with scaled as (2) ", "Moderately / Sometime true with scaled as (3)","Highly / Usually true with scaled as (4)", "Extremely / Always True with scaled as (5)", The Anxiety score average was evaluated by statements as "Extremely High Anxiety (6)","High Test Anxiety (5)","Moderately High Test Anxiety (4)","High Normal Test Anxiety (3)", "Normal Average Test Anxiety (2)", "Low Test Anxiety (1)". Reliability of the questionnaire has verified by Cronbach's Alpha $=0.789, \mathrm{~N}=12$

\section{Data collection procedure}

The researcher, acquired the official consent and considered a convenience for herself as well as for head of the institute or exams center superintendent during the procedure of data collection. Questionnaires were distributed to participants Willing to fill in the answers on the bases of their personal feelings of worries and symptoms the have before / during and after an exam in the selected examination center before the beginning of the test /exam Researcher assured the confidentiality of the personal information and also guaranteed that the material provided was only used for research purpose. 
Pakistan Journal of Educational Research. Vol 2, Issue 2 (2019)

Effects of exam.

\section{DATA ANALYSIS \& RESULTS}

For analyzing and interpreting quantitative results (mean, standard deviation and an Independent sample $t$ - test) was performed by using SPSS 20 (Statistical Package of Social Science)

\section{Table 1}

Descriptive Statistics

\begin{tabular}{llccc}
\hline & Gender & N & Mean & $\begin{array}{c}\text { Std. } \\
\text { Deviation }\end{array}$ \\
\hline $\begin{array}{l}\text { Test anxiety } \\
\text { score }\end{array}$ & Male & 102 & 3.2451 & .70971 \\
& & & & \\
\hline
\end{tabular}

Table 2

Independent Samples Test ( t-test for Equality of Means)

\begin{tabular}{llllllll}
\hline & T & Df & $\begin{array}{l}\text { Sig. } \\
(2- \\
\text { tailed })\end{array}$ & $\begin{array}{l}\text { Mean } \\
\text { Difference }\end{array}$ & $\begin{array}{l}\text { Std. Error } \\
\text { Difference }\end{array}$ & \multicolumn{2}{l}{$\begin{array}{l}\text { In\% Confidence } \\
\text { Inval of the } \\
\text { Difference } \\
\text { Lower }\end{array}$} \\
\hline $\begin{array}{l}\text { Average } \\
\text { Test }\end{array}$ & -1.682 & 170 & .094 & -.18347 & .10911 & -.39886 & .03191 \\
$\begin{array}{l}\text { Anxiety } \\
\text { Scores }\end{array}$ & -1.689 & 150.7 & .093 & -.18347 & .10863 & -.39810 & .03116 \\
\hline
\end{tabular}

The perusal of (table 1) revealed that calculated values of data, the boys $(\mathrm{N}=$ $102, \mathrm{M}=3.2451, \mathrm{SD}=0.709710)$, and the girls $(\mathrm{N}=70, \mathrm{M}=3.4143, \mathrm{SD}=$ 0.60176). Close examine of (Table 2) concluded as there is no difference in the mean value (-.18347), We assumed that average mean of the variables indicated statistically insignificant difference. For evaluating the variance among genders in Test anxiety Average scores, an Independent sample t - test was performed on SPSS. The results has revealed (table 2) $\mathrm{TS}=\mathrm{t}(170)=, \mathrm{p}=0.094$, as calculated t-test statistic $p=.094>(\alpha=0.05)$, at 95\% confidence interval ,the " $t$ " value lies between $(-0.0319-0.0311)$, it has been concluded by the results that there's insignificant difference in test anxiety scores in boys and 
girls. Therefore, the null hypothesis has been accepted as there's statistically no significant gender variance in anxiety level in boys and girls at Public secondary schools, in District, Quetta. Results analysis concluded that alternative hypothesis has been rejected as there was no statistically significant gender variance in anxiety level in boys and girls at Public secondary schools, in District, Quetta.

\begin{tabular}{llccc}
\multicolumn{4}{l}{ Mean Average Test } & \multicolumn{3}{c}{ Anxiety } & Scores among & Gender (Table2) \\
\hline & Gender & N & Mean & $\begin{array}{c}\text { St. } \\
\text { Deviation }\end{array}$ \\
\hline $\begin{array}{l}\text { Test } \\
\text { anxiety } \\
\text { score }\end{array}$ & Male & 102 & 3.2451 & .70971 \\
\hline
\end{tabular}

Figure 1. Graph of Average Test Anxiety Scores among Gender

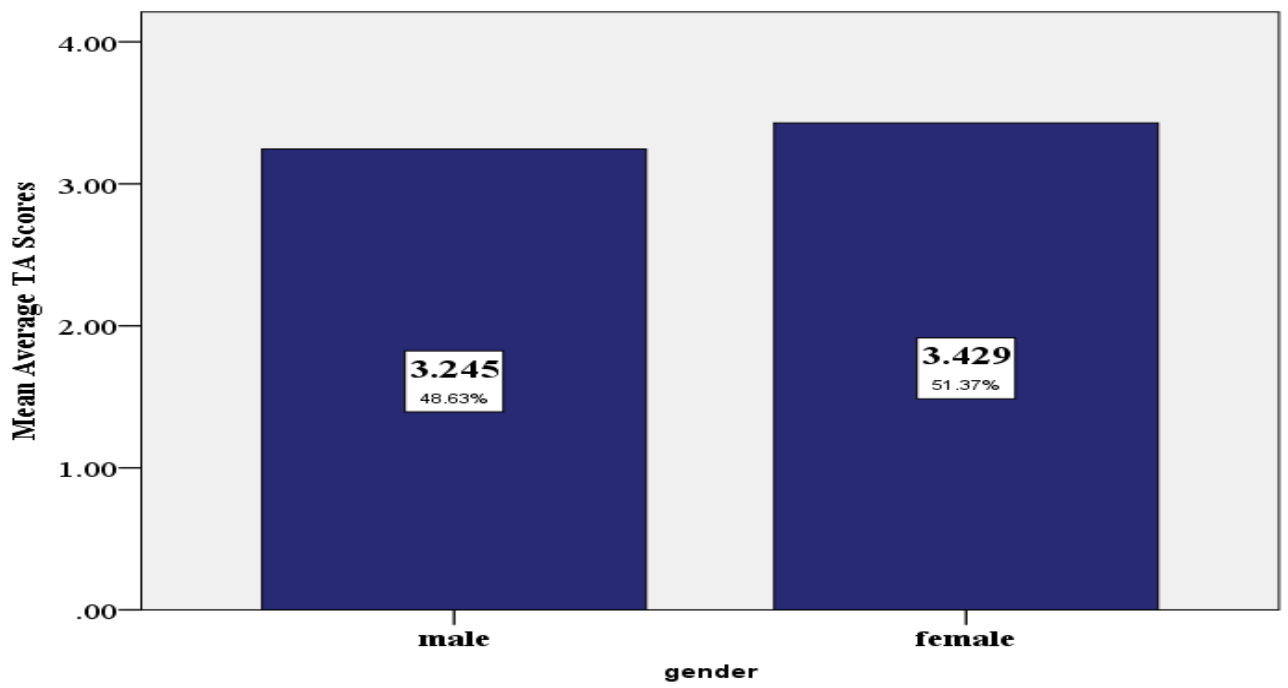

\section{Result:}

(figure 1) bar chart clearly presented the insignificant mean difference between male ( $\mathrm{N}=102, \mathrm{M}=3.2451)$ and female $(\mathrm{N}=70, \mathrm{M}=3.4143)$ that is about ( 0.184) which has proven the existence of a slight differences in test anxiety scores in both genders. As the difference was minor therefore not clearly indicated though female bar showed $51.37 \%$ and male bar showed $48.63 \%$ anxiety score 
Table 3

Average Test Anxiety Scores in Percentage

\begin{tabular}{lllll}
\hline \multicolumn{1}{c}{ Label } & Frequency & Percentage & $\begin{array}{c}\text { Valid } \\
\text { \% age }\end{array}$ & $\begin{array}{c}\text { Cumulative } \\
\text { \%age }\end{array}$ \\
\hline $\begin{array}{l}\text { Low- Test Anxiety } \\
\text { Average/Normal }\end{array}$ & 2 & 1.1 & 1.2 & 1.2 \\
$\begin{array}{l}\text { Test Anxiety } \\
\text { High Normal Test }\end{array}$ & 84 & 8.4 & 8.7 & 9.9 \\
$\begin{array}{l}\text { Anxiety } \\
\text { Moderately High- }\end{array}$ & 68 & 47.2 & 48.8 & 58.7 \\
$\begin{array}{l}\text { Test Anxiety } \\
\text { High Test Anxiety }\end{array}$ & 3 & 38.2 & 39.5 & 98.3 \\
Total & 172 & 1.7 & 1.7 & 100.0 \\
\hline
\end{tabular}

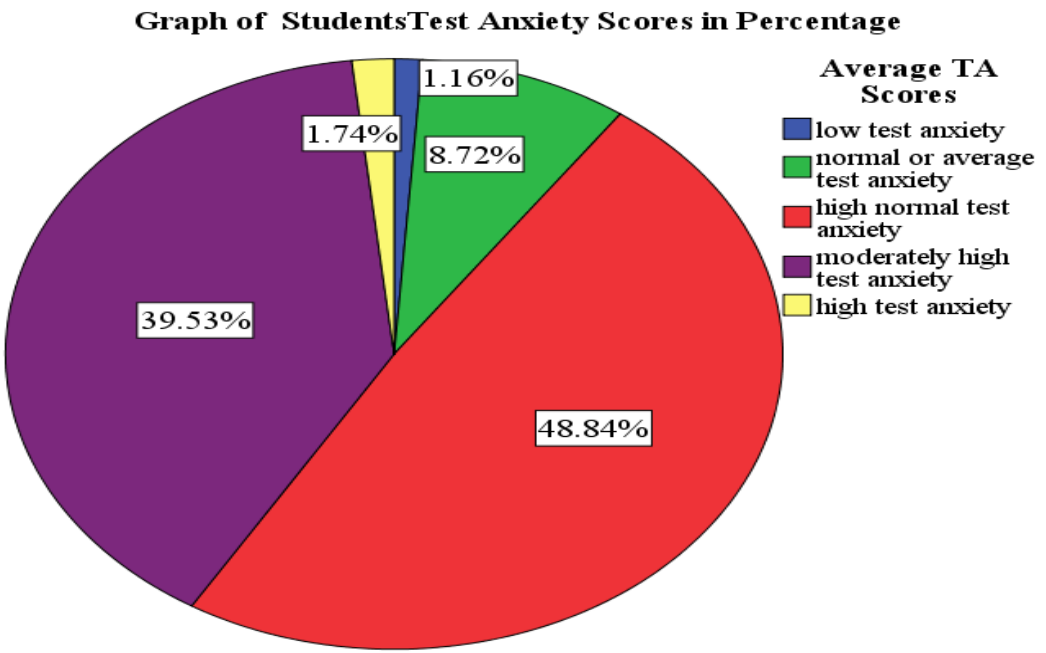

Figure 2. Graph of students' anxiety levels in percentage

\section{Result:}

A clear examination (table 3) and (Figure 2) concluded that Total (172) students reported with test anxiety, among collected and analyzed data $1.16 \%$ Students reported with low test anxiety,8.72 \% Students reported with normal or average test anxiety, $48.84 \%$ Students reported with high normal test anxiety, 
Pakistan Journal of Educational Research. Vol 2, Issue 2 (2019)

Effects of exam...

$39.53 \%$ Students reported with moderately high test anxiety and $1.74 \%$ Students reported with high test anxiety

Table 4

Gender / AverageTest Anxiety Socres

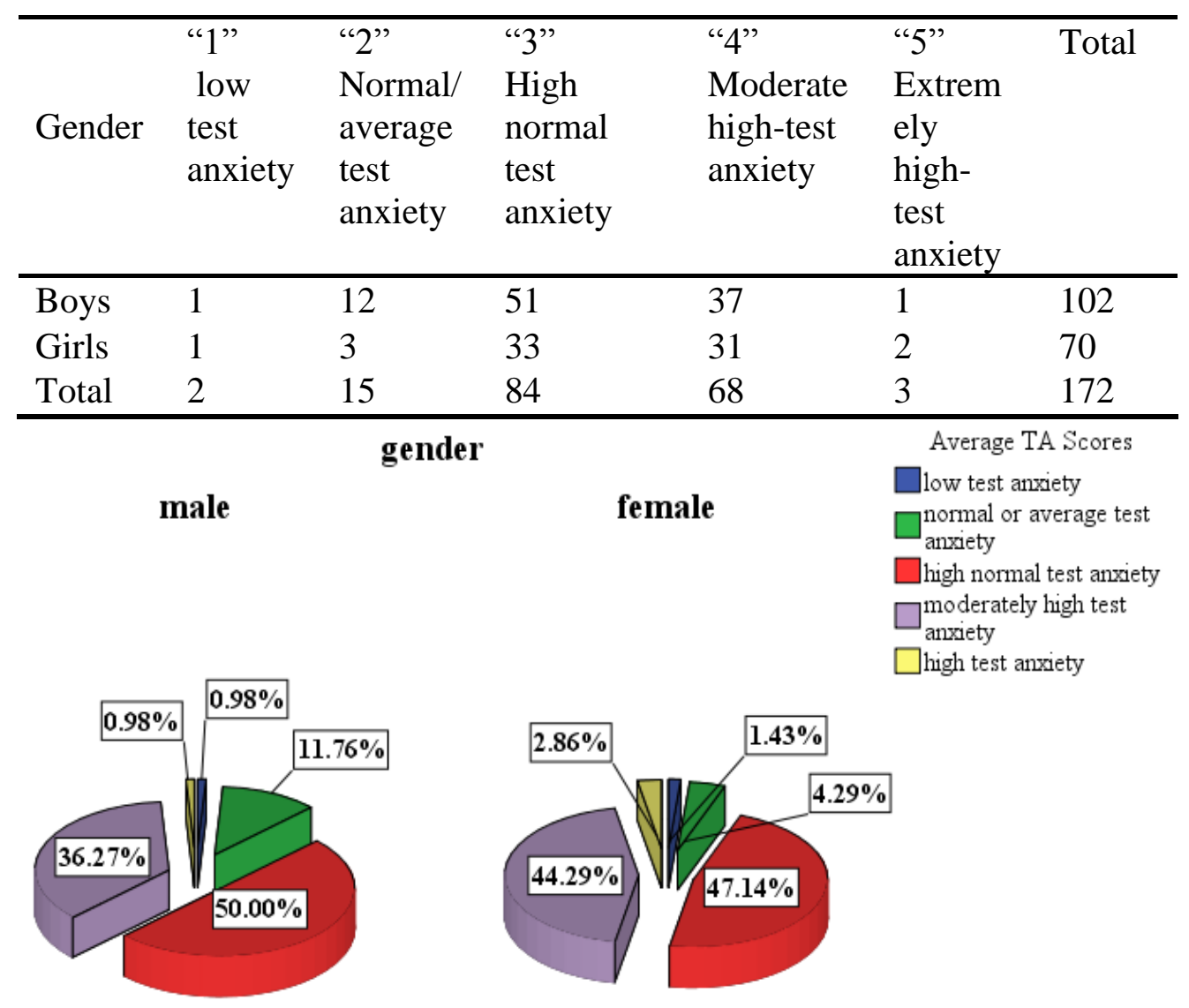

Figure 3. Gender wise Average test anxiety scores

\section{Result:}

(Table 4) Total $\mathrm{n}=172$ (102 boys and 70 girls) respondents were analyzed. Analyzed data revealed that among boys ,1(.98\%) respondent testified with low anxiety, $12(11.76 \%)$ respondents testified normal or average test anxiety, $51(50 \%)$ high normal test anxiety, $37(36.27 \%)$ respondents testified with moderately high-test anxiety and $1(.98 \%)$ respondent testified with extremely 
high-test anxiety. Therefore, totally $99 \%$ of male respondents are experiencing test anxiety in appearing examination. On the other hand, among girls' respondents $1(1.43 \%)$ respondent has revealed with low anxiety, $3(4.29 \%)$ respondents showed high normal test anxiety, 33 (47.14\%) respondents showed with moderately high-test anxiety and $2(2.86 \%)$ revealed with extremely hightest anxiety, totally $97 \%$ female respondents are experiencing anxiety. The result of the present study confirmed that both boys and girls were feeling anxious at time of exams.no identical variation was detected, only females reported by slightly more anxious than males.

\section{Table 5}

Gender Test anxiety scores difference in percentages

\begin{tabular}{llllll}
\hline Gender & $\begin{array}{l}\text { low } \\
\text { test } \\
\text { anxiety }\end{array}$ & $\begin{array}{l}\text { normal } \\
\text { average } \\
\text { test } \\
\text { anxiety }\end{array}$ & $\begin{array}{l}\text { high } \\
\text { normal } \\
\text { test } \\
\text { anxiety }\end{array}$ & $\begin{array}{l}\text { Moderately } \\
\text { high test } \\
\text { anxiety }\end{array}$ & $\begin{array}{l}\text { extremely } \\
\text { high-test } \\
\text { anxiety }\end{array}$ \\
\hline Boys & $50 \%$ & $80 \%$ & $60.71 \%$ & $54.41 \%$ & $33.33 \%$ \\
Girls & $50 \%$ & $20 \%$ & $39.29 \%$ & $45.59 \%$ & $66.77 \%$ \\
Total & $100 \%$ & $100 \%$ & $100 \%$ & $100 \%$ & $100 \%$ \\
\hline
\end{tabular}

Graph for Test anxiety level difference in gender
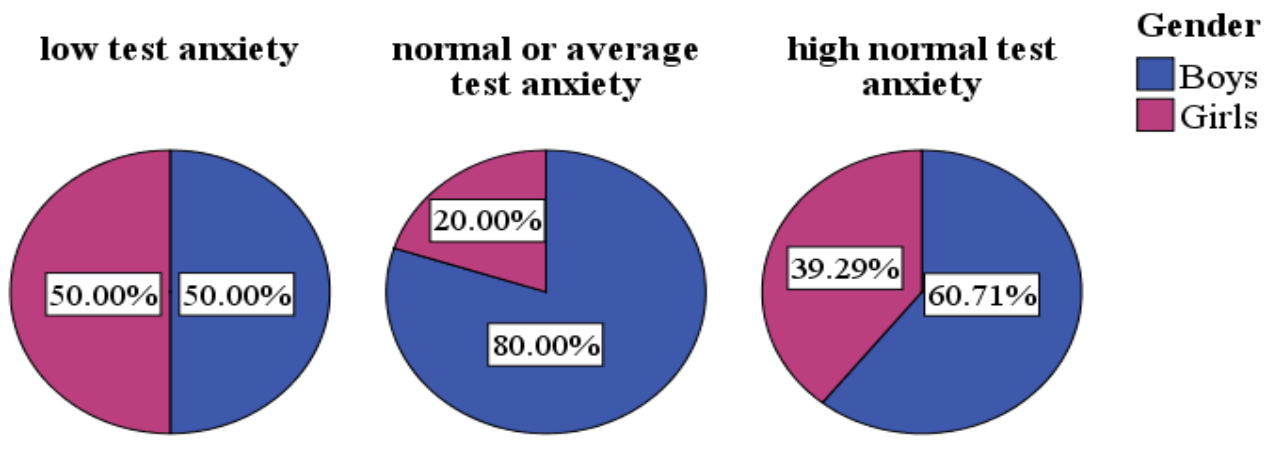

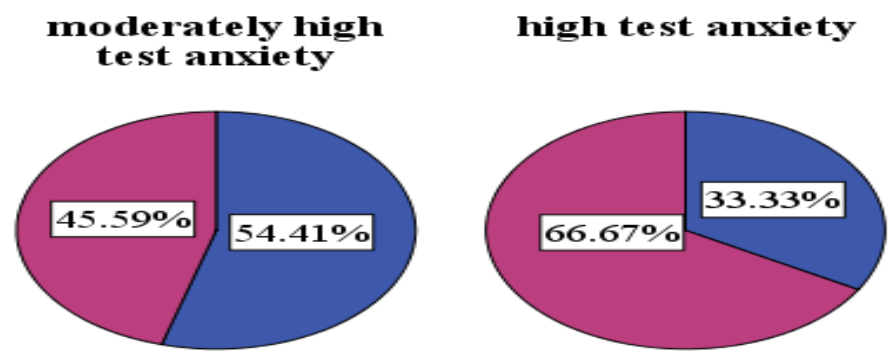

Figure 4. Graph of Gender Test anxiety scores difference in percentages

\section{Result:}

Total $n=172$ (102 boys and 70 girls) respondents were analyzed for their anxiety level. Evaluated data discovered that (50\%) boys and (50\%) girls respondents showed with low anxiety, (80\%) boys and (20\%) girls respondents showed with extremely high-test anxiety, boys $(60.71 \%)$ and $(39.29 \%)$ girls respondents showed with normal or average test anxiety ,51(29.65\%) showed high normal test anxiety , (54.41\%) boys and (45.59\%) girls respondents showed with moderately high test anxiety and $(33.33 \%)$ boys and $(66.77 \%)$ girls respondents showed with extremely high anxiety .The result of the present study proven presence of test anxiety in both boys and girls but insignificant variation was detected in gender anxiety level, however, boys percentage was founded higher than girls.

\section{DISCUSSION}

The current study intended to investigate the mental and emotional reaction of students in an evaluative situation. Test anxiety or exam anxiety is considered as a normal response of the student in the examination. Zollar \& Ben-chain (1990) research had the opinion that "we are members of test conscious age, which severely affecting overall performances of an individuals in evaluative condition. Stress before the exam is thwarting students to utilize their potential for maximum level (Zollar et al., 1990 as cited Spielberger, 1985).

A moderated or average level anxiety helps in improving effectiveness and motivation for hardworking students in examinations. The current study revealed that student's extreme anxiety resulted in somatic signs of arousal of depression, deteriorate thoughts and perceptions and catastrophic feelings in testing circumstances. The research findings claimed that pupils with little anxiety had greater academic performances as compared to students with 
modest and greater anxiety, similarly pupils with modest anxiety had a greater academic performance as compare to students with greater test-anxiety (Zamir. $\mathrm{S}$ et al, 2013). The research further concluded that extreme level selfperceptions regarding the comparison of self-achievements with other fellows, underestimating their own self-confidence and capabilities in comparison to others leads towards excessive tension and anxiety in the examination.

Our research results did not confirm gender variation between both girls and boys in test anxiety scores.as our result is not congruous with previous studies. The gender variation is statistically insignificant in anxiety levels. There is only $(0.184 \%)$ variation in mean value between male and female student's anxiety scores. As all learners are similarly suffering anxiety in judgmental situations irrespective to their sex and has adverse effect of anxiety on their accomplishments, therefore they required equal opportunities as students in coping with anxiety attack in evaluative state (Rana, R \& Masood, N 2010; Javanbakht \& Hadian, 2014).

Contrary to expectation Our present investigation hasn't detected a statistically significant gender variation in the levels of exam anxiety state of examination. (Crişana.C \& Copacib.C ,2014; Yeo, Tan \& Lew, 2015). In the responding to the research question of the investigation, it is concluded that there is insignificant difference in the arithmetic mean value of both boys and girls in anxiety scores. There is undistinguishable variation in response to questions from the questionnaire which indicated that both groups showed association with test anxiety. Our research findings are inconsistence with previous studies in the presence of anxiety in girls and boys, but unable to detecting variation in test anxiety score in both genders. These results are not congruent to preceding studies, the gender variation is statistically insignificant in anxiety levels. There is only $0.184 \%$ variation in means between male and female students' anxiety scores (Crişana. C \& Copacib. C, 2014; Isabel. M \& Peñaa. N, et al.,2016). As a girl's average mean of anxiety scores is slightly higher as compared to boys' learners., So the study concluded that female learners are expressively high emotional and worrisome nature and high-level anxiety in contrast to male learner which are less expressive emotional nature due to their masculine dignity. 


\section{RECOMMENDATIONS}

It is absolutely crucial that exam Anxiety affects leads towards decline in academic achievements, hindering cognitive functioning, emotional crack down therefore study recommended.

Family, teacher, educational institutions should provide assistance to students in coping with anxiety by following anxiety managing strategies.

Appropriate training must be arranged for students' behavioural therapies, counselling, self-instructional and self-relaxation strategies.

It is absolutely necessary for the learner to scrutinized their cognitive working, physical capabilities and skills on periodic bases.

Students play crucial role in anxiety reduction procedure by, learning how to manage your perceptions about test, avoid over thinking, never believe on rumors and believes on reliable resources for test guidance instead of wasting time on irrelevant strategies, collect all necessary information about test sequence, contents and test environment. students should adopt healthy habits for studying, because a healthy diet and regular.

exercise is extremely helpful in anxiety reduction. (Gürses.A et al., 2010).

Use anxiety as motivational force while performing to your maximum level of abilities. Always ask for expert assistance if you are unable to manage your anxious condition.

Research findings are beneficial for overall progression of educational achievements of schoolchildren in all levels of school. Further investigation is required in future for developing more effective anxiety reduction techniques for student's support. to promote emotional and psychological wellbeing the research can endorse overall healthiness in the educational system as well in the communities.

\section{REFERENCES}

Atkinson, J. W., \& Feather, N. T. (Eds.). (1966). A theory of achievement motivation (Vol. 6). New York: Wiley.

Anxiety. (2000) Encyclopedia of Psychology. American Psychological Association. Retrieved from: http://www.apa.org/topics/anxiety/

Bandura, A. (1993). Perceived self-efficacy in cognitive development \& un-counting Educational psychologist, 28(2), 117-148.

Barrows, J., Dunn, S., \& Lloyd, C. A. (2013). Anxiety, self-efficacy, and college 
exam grades. Universal Journal of Educational Research, 1(3), 204-208.

Breuer, A. (1999). Biofeedback and Anxiety. Psychiatric Times, 16 (2), 12. Cassady, J. C., \&

Johnson, R. E. (2002). Cognitive test anxiety and academic performance. Contemporary educational psychology, 27(2), 270-295.

Dawood, E., Al Ghadeer, H., Mitsu, R., Almutary, N., \& Alenezi, B. (2016). Relationship between Test Anxiety and Academic Achievement among Undergraduate Nursing Students. Journal of Education \& Practice,7(2),5765.

Derakshan, N., \& Eysenck, M. W. (2009). Anxiety, processing efficiency, and cognitiveperformance: New developments from attentional control theory. European Psychologist, 14(2), 168-176.

Eubank, C. C. (1993). The relationship among test anxiety, academic achievement, and age in associate degree nursing students (Doctoral dissertation, Drake University)

Ergene, T. (2011). The relationships among test anxiety study habits achievement motivation and academic performance among Turkish secondary school students. Egitim ve Bilim, 36(160), 320.

Farooqi, Y. N., Ghani, R., \& Spielberger, C. D. (2012). Gender differences in test anxiety and academic performance of medical students. International Journal of Psychology and Behavioral Sciences, 2(2), 38-43

Ferdous, F. (2012), “A case study of first-year-non-English Undergraduate student's English learning anxiety in Bangladesh", Journal of Education and Practice, Vol. 3 No. 9, pp. 1-11.

Gürses, A., Kaya, Ö., Doğar, Ç., Günes, K., \& Yolcu, H. H. (2010). Measurement of secondary school students' test-anxiety levels and investigation of their causes. Procedia-Social and Behavioral Sciences, 9, 1005-1008

Harris, B. (2013). International school-based counselling: A review of school-based counselling internationally. British Association for Counselling \& Psychotherapy and Department of Health.

Hembree, R. (1988). Correlates, causes, effects, and treatment of test anxiety. Review of educational research, 58(1), 47-77.

Khan, M. S., Mahmood, S., Badshah, A., Ali, S. U., \& Jamal, Y. (2006). Prevalence of depression, anxiety and their associated factors among medical students in Karachi, Pakistan. Journal-Pakistan Medical Association, 56(12), 583.

Khuwaja, A. K., Qureshi, R., \& Azam, S. I. (2004). Prevalence and factors associated with anxiety and depression among family practitioners in Karachi, Pakistan. Journal-Pakistan Medical Association, 54(2)

Liebert, R. M., \& Morris, L. W. (1967). Cognitive and emotional components of test anxiety: A distinction and some initial data. Psychological reports, 20(3), 975-978 
Mathews, J. C. (1985). Examinations: a commentary. Allen \& Unwin

Minahan, J., \& Rappaport, N. (2012). Anxiety in students A hidden culprit in behavior issues. Phi Delta Kappan, 94(4), 34-39

Nadeem, M., Ali, A., Maqbool, S., \& Zaidi, S. U. (2012). Impact of anxiety on the academic achievement of students having different mental abilities at university level in Bahawalpur (Southern Punjab) Pakistan. International Online Journal of Educational Sciences, 4(3), 519-528

Ndirangu, G. W., Muola, J. M., Kithuka, M. R., \& Nassiuma, D. K. (2009). An investigation of the relationship between test anxiety and academic performance in secondary schools in Nyeri District, Kenya. Global journal of educational research, 8(1-2).

Numan, A., \& Hasan, S. S. (2017). Effect of Study Habits on Test Anxiety and Academic Achievement of Undergraduate Students. Journal of Research \& Reflections in Education (JRRE), 11(1).

Patrick, J. R. (1934). Studies in rational behavior and emotional excitement. II. The effect of emotional excitement on rational behavior in human subjects. Journal of Comparative Psychology, 18(2), 153

Putwain, D. W. (2007). Test anxiety in UK schoolchildren: Prevalence and demographic patterns. British Journal of Educational Psychology, 77(3), 579-593

Rafiq, R., Ghazal, S., \& Farooqi, Y. N. (2007). Test anxiety in students: semester's vs. annual system. Journal of Behavioural Sciences, 17(1/2), 79

Rana, R., \& Mahmood, N. (2010). The relationship between test anxiety and academic achievement. Bulletin of education and research, vol .32, No.2 pp.63-74

Rasul, S., \&Bukhsh, Q. (2011). A study of factors affecting students' performance in examination at university level. Procedia-Social and Behavioral Sciences, 15, 2042-2047.

Rezazadeh, M., \& Tavakoli, M. (2009). Investigating the Relationship among Test Anxiety, Gender, Academic Achievement and Years of Study: A Case of Iranian EFL University Students. English Language Teaching, 2(4), 68-74

Ruffins, P. (2007). A real fear: It's more than stage fright, math anxiety can derail academic or professional success, but some scholars are working to help students get over it. Diverse Issues in Higher Education. Findarticle. com (online) http://findarticles.com/p/articles/mi_mOWMX/is_2_24/ai_n18744928

McDonald, A. S. (2001). The prevalence and effects of test anxiety in school children. Educational psychology, 21(1), 89-101

Mandler, G., \&Sarason, S. B. (1952). A study of anxiety and learning. The Journal of Abnormal and Social Psychology, 47(2), 166.

Sarason, S. B., Davidson, K. S., Lighthall, F. F., Waite, R. R., \&Ruebush, B. K. 
(1960). Anxiety in elementary school children: A report of research.

Sarason, I. G. (1984). Stress, anxiety, and cognitive interference: reactions to tests. Journal of personality and social psychology, 46(4), 929

Shiri, M., Akhavan, S., \&Geramian, N. (2012). Anxiety Disorder and Its Types. In Essential Notes in Psychiatry. InTech.

Sharma, S., \& Sud, A. (1990). Examination stress and test anxiety: A cross-cultural perspective. Psychology and Developing Societies, 2(2), 183-201

Spielberger, C. D. (1966). Theory and research on anxiety. In C. D. Spielberger (Ed.), Anxiety and behavior. New York: Academic Press.

Spielberger, C. D. (1985). Stress and anxiety (Vol. 7, No. 1-4). Taylor \& Francis

Stöber, J., \&Pekrun, R. (2004). Advances in test anxiety research.

Sullivan, H. S. (1949). The theory of anxiety and the nature of psychotherapy. Psychiatry, 12(1), 3-12.

Tobias, S. (1979). Anxiety research in educational psychology. Journal of Educational Psychology, 71(5), 573.

Tobias, S. (1985). Test anxiety: Interference, defective skills, and cognitive capacity. Educational Psychologist, 20(3), 135-142

Trifoni, A., \& Shahini, M. (2011). How does exam anxiety affect the performance of university students. Mediterranean Journal of Social Sciences, 2(2), 93-100.

Udeani, U. (2012). The relationship between study habits, test anxiety and science achievement. Journal of Education and Practice, 3(8), 151-157.

Vitasari, P., Wahab, M. N. A., Othman, A., Herawan, T., \& Sinnadurai, S. K. (2010). The relationship between study anxiety and academic performance among engineering students. Procedia-Social and Behavioral Sciences, 8, 490-497

Xiao, J. (2013). Academic stress, test anxiety, and performance in a Chinese high school sample:The moderating effects of coping strategies and perceived social support.

Yousefi, Mansor, M., Juhari, R., Redzuau, M., Talib, M. and Kumar, V. (2009), "Memory as mediator between test anxiety and academic achievement in high school students", European Journal of Science Research, Vol. 35 No. 2, pp. 274-280.

Zaheri, F., Shahoei, R., \& Zaheri, H. (2012). Gender differences in test anxiety among students of guidance schools in Sanandaj, Iran. Wudpecker Journal of Medical Sciences, 1(1), 001-005.

Zahrakar, K. (2008). Stress counseling (antecedents, consequences and therapeutic strategies of sress). Tehran: $B A A L$

Zamir, S., \& Hina, Q. A.(2013) The relationship between test anxiety and academic achievement of students at university level. Journal of Education and Practice, Vol.5, No.4,ISSN 2222-1735 (Paper) 
Pakistan Journal of Educational Research, Vol 2. Issue 2 (2019) Effects of exam...

Zeidner, M. (1990). Does test anxiety bias scholastic aptitude test performance by gender and sociocultural group?. Journal of personality assessment, 55(1-2), 145-160.

Zeidner, M. (1998). Test anxiety: The state of the art. Springer Science \& Business Media

Zoccolillo, M. (1988). Major depression during medical training. JAMA, 260(17), $2560-2561$ 